\title{
Anatomic Variation of the Submandibular Gland: A Case Report
}

\author{
Variación Anatómica de la Glándula Submandibular: Reporte de Caso
}

\begin{abstract}
André Luiz Silva Davim*; Cintia Raquel Lima**; Edmilson Gomes Silva Junior**; Natália Crislly Albuquerque da Silva**; Priscilla Paula Fonseca Costa**; Maria Luiza Gomes Freire**; Ravel Marinho Cavalcante**; João Faustino da Silva Neto*** \& Diego Filgueira Albuquerque***
\end{abstract}

DAVIM, A. L. S.; LIMA, C. R.; SILVA JUNIOR, E. G.; DA SILVA, N. C. A.; COSTA, P. P. F.; FREIRE, M. L. G.; CAVAlCANTE, R. M.; DA SILVA NETO, J. F. \& ALBUQUERQUE, D. F. Anatomic variation of the submandibular gland: a case report. Int. J. Med. Surg. Sci., 2(3):579-582, 2015.

SUMMARY: The Human Anatomy is an ancient Science, which uses the human body as the main material of study. However, structural differences between individuals that make up the species are quite common in the population and always emerge as a source of reports that aim to demonstrate and clarify these differences. These structural changes are called anatomical variations and may be presented externally or internally in any of the body systems, with no functional impairment to the individual. The salivary glands are exocrine glands that secrete saliva directly into the mouth through their ducts. This secretion has the functions of keeping mucous membranes moist, cleaning teeth, lubricating, dissolving and starting the food digestion process. Most of the saliva is secreted by the major salivary glands, the parotid glands and the submandibular glands, the latter being the focus of this case report. The purpose of this paper is to report a case of finding an accessory submandibular gland on a cadaver from the Human Anatomy Laboratory of the University Center of Rio Grande do Norte located in Natal, Rio Grande do Norte, Brazil. The discovery was made during a dissection of an adult male body in 2012, where an accessory submandibular gland was found in the right antimere. Thus, by identifying such variations, its clinical importance can be observed for the purpose of diagnostic imaging, surgery and anatomical teaching applied to clinic, given the scarcity of published reports, thus providing better understanding those working directly or indirectly on the subject.

KEY WORDS: Submandibular gland; Anatomic variation; Cadaver.

\section{INTRODUCTION}

The Human Anatomy is an ancient science that studies the formation and development of organic beings (Vidsiunas et al., 2008), and uses as the main material of study the human body. A thorough inspection of external and internal parts is necessary for this study, seeking direct observation and study of three-dimensional structures, which are considered essential conditions for learning (Fornaziero \& Gil, 2003). These studies can be done in living beings, using modern imaging techniques such as computerized tomography (CT) and magnetic resonance imaging (MRI), as well as the traditional method used in universities, which is the dissection of cadaver, common practice in Human anatomy labs in higher education institutions around the world. The practice of dissection of cadaver is of great importance, as it is through this practice that structural differences are observed. These are called anatomicalvariations and are extremely common among the specimens, being presented externally or internally in any of the systems that make up the body characterized, and not

* Adjunct Professor of Human Anatomy. University Center of Rio Grande do Norte - UNI-RN, Natal, Brazil.

** Graduate Students of health course University Center of Rio Grande do Norte - UNI-RN, Natal, Brazil.

*** Assistent Professor of Human Anatomy. University Center of Rio Grande do Norte - UNI-RN, Natal, Brazil. 
DAVIM, A. L. S.; LIMA, C. R.; SILVA JUNIOR, E. G.; DA SILVA, N. C. A.; COSTA, P. P. F.; FREIRE, M. L. G.; CAVALCANTE, R. M.; DA SILVA NETO, J. F. \& ALBUQUERQUE, D. F. Anatomic variation of the submandibular gland: a case report. Int. J. Med. Surg. Sci., 2(3):579-582, 2015.

leading to functional impairment to the individual.

According to Tortora \& Nielsen (2013), salivary glands are many, being located in the mucosa of the mouth and tongue, secreting saliva directly or indirectly in the mouth through ducts. These glands, called minor salivary glands, are the lip, cheek, palate and tongue glands. Other salivary glands, called major, are located outside the oral mucosa, which are the parotid, the submandibular and the sublingual. All these glands are attached to the digestive system and secrete saliva directly into the mouth through its ducts and channels. This secretion has various functions of keeping mucous membranes moist, cleaning teeth, lubricating, dissolving and starting the digestion of food. The submandibular glands overlap the mylohyoid muscle and that originates from the medial surface of the mandible, inserting the hyoid bone and being the supporting structure of the oral mouth base that separates the sublingual space from the submandibular space (Souza et al., 2003). The submandibular glands are bilaterally situated below the base of the tongue, before the lower part of the parotid gland, secreting saliva directly into the mouth by means of their ducts, which lie on either side of the midline of the mouth base, beside thetongue frenulum. Moreover, they are irrigated by branches of the facial artery and drained by tributaries of the facial veins, receiving facial and glossopharyngeal nerve fibers. According to Moore (2013), students should expect anatomical variations when dissecting or studying dissected specimens.

Given the lack of published reports in relation to changes in the submandibular gland, the purpose of this paper is to report a case of finding an accessory submandibular gland (variant) in a cadaver from the Human Anatomy Laboratory of the University Center of Rio Grande do Norte, located in Natal, Rio Grande do Norte, Brazil.

\section{CASE REPORT}

Routine dissection one was held at the Human Anatomy Laboratory of the University
Center of Rio Grande do Norte - UNI-RN, in Natal in 2012. The dissection was performed in an adult male body, black ethnicity, with slender biotype. After finding the gland variant (Fig. 1), it was measured in length and width using digital caliper.

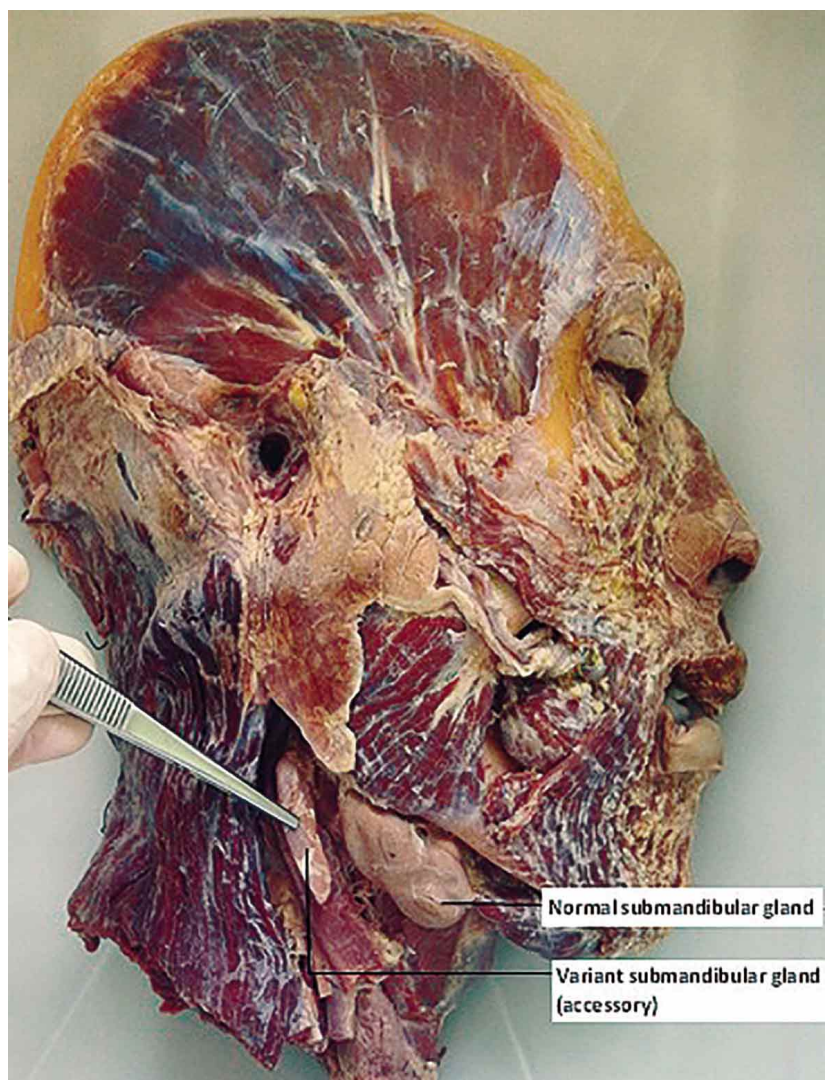

Fig. 1. Accessory submandibular gland.

An accessory submandibular gland was found and observed after the subcutaneous tissue of the right antimere the face of the cadaver was dissected, located posterior-inferior to the submandibular non-variant gland. The gland variant measured $37.49 \mathrm{~mm}$ in length by $6.52 \mathrm{~mm}$ in width (values obtained by the measurement using the caliper), with smaller size compared to the non-variant, which measured $41.55 \mathrm{~mm}$ and $19.31 \mathrm{~mm}$ in length and width, respectively (Fig. 1). There was no presence of variant gland on the opposite antimere. Among most anatomical variations described in the literature, we may highlight reports of vascular changes (arteries and veins) as well as organs, such as dextrocardia and situs 
DAVIM, A. L. S.; LIMA, C. R.; SILVA JUNIOR, E. G.; DA SILVA, N. C. A.; COSTA, P. P. F.; FREIRE, M. L. G.; CAVALCANTE, R. M.; DA SILVA NETO, J. F. \& ALBUQUeRQUE, D. F. Anatomic variation of the submandibular gland: a case report. Int. J. Med. Surg. Sci., 2(3):579-582, 2015.

inversus totalis, being some of the most mentioned variations. The practice of dissection of cadaver is very important because it allows one to verify the possible existence of structural differences in the human body, and for Vasconcelos et al. (2012), studies of anatomical variations of salivary glands, specifically the submandibular gland, are scarce. In an anatomical study of the blood vessels model responsible for the blood supply of the submandibular gland of Neotropical primates conducted by Oliveira et al. (2000), accessory submandibular glands were found in two specimens of the thirty antimeres analyzed, located before the main gland and presenting rounded shape, and smaller size and volume.

The accessory submandibular glands had independent blood supply, allowing the consideration that their obstruction does not compromise the vascularity of the region, should it be removed surgically. However, Vasconcelos also states that the vast majority of publications involving the submandibular gland cover mostly clinical variations, such as the presence of sialotilo characteristic of calcification of these glands' ductal system; not as frequently studies are published portraying only anatomical variations of this gland. Most studies on the salivary glands regard the epidemiology of cancers, and of the anatomical location site of gland tumors, the submandibular is the second most frequent, behind only the parotid, according to Loiola (2009) and Kruschewsky (2011). These variations found by dissecting cadavers are important report sources that aim to demonstrate and clarify the differences between the specimens, says Davim et al. (2010).

DAVIM, A. L. S.; LIMA, C. R.; SILVA JUNIOR, E. G.; DA SILVA, N. C. A.; COSTA, P. P. F.; FREIRE, M. L. G.; CAVALCANTE, R. M.; DA SILVA NETO, J. F. \& ALBUQUERQUE, D. F. Variación anatómica de la glándula submandibular: Reporte de caso. Int. J. Med. Surg. Sci., 2(3):579-582, 2015.

RESUMEN: La anatomía humana es una ciencia antigua, que posee al cuerpo humano como principal material de estudio. Sin embargo, las diferencias estructurales entre los individuos son muy comunes en la población y siempre surgen como una fuente de los informes que tienen como objetivo demostrar y aclarar estas diferencias. Estos cambios estructurales se denominan variaciones anatómicas y pueden presentarse externa o internamente en cualquiera de los sistemas del cuerpo, sin provocar un deterioro funcional en el individuo. Las glándulas salivales son glándulas exocrinas que secretan saliva directamente en la boca a través de sus conductos. Esta secreción cumple las funciones de mantenimiento de las membranas mucosas húmedas, limpieza de los dientes, lubricante, disolviendo e iniciando el proceso de digestión de los alimentos. La mayor parte de la saliva es secretada por las glándulas salivales, las glándulas parótidas y las glándulas submandibulares, siendo estas últimas las que se considerarán en este trabajo. El propósito de esta investigación consiste en reportar un caso de glándula submandibular accesoria en un cadáver proveniente del Laboratorio de Anatomía Humana de la Universidad del Centro de Río Grande del Norte, ubicado en Natal, Río Grande del Norte, Brasil. El hallazgo se llevó en el año 2012 durante una disección de rutina de un cadáver masculino adulto, en el cual se encontró una glándula submandibular accesoria. Por lo tanto, mediante la identificación de tales variaciones, se puede observar la importancia clínica de esta variación al efectuar su diagnóstico por imagen, como así también en el ámbito de la cirugía y la enseñanza anatómica aplicada a la clínica, debido a la escasez de informes publicados sobre este tipo de variaciones anatómicas, proporcionando así una mejor comprensión para aquellos profesionales que trabajan directa o indirectamente sobre el tema.

PALABRAS CLAVE: Glándula submandibular; Variación anatómica; Cadáver.

\section{REFERENCES}

Davim, A. L. S.; Neto, J. F. S. \& Albuquerque, D. F. Anatomical variation of the superior cerebelar artery: a case study. J. Morphol. Sci., 27(34): $155-6,2010$.
Fornaziero, C. C. \& Gil, C. R. Novas tecnologias aplicadas ao ensino da anatomia humana. Rev. Bras. Educ. Med., 27(1):141-6, 2003. 
DAVIM, A. L. S.; LIMA, C. R.; Silva JUNIOR, E. G.; DA SilVA, N. C. A.; COSTA, P. P. F.; FREIRE, M. L. G.; CAVALCANTE, R. M.; DA SILVA NETO, J. F. \& ALBUQUERQUE, D. F. Anatomic variation of the submandibular gland: a case report. Int. J. Med. Surg. Sci., 2(3):579-582, 2015.

Kruschewsky, L. S.; Castro, T.; Schear, H.; Ramos, E.; Kruschewsky, M. B.; dos Santos, J. N. \& de Mello-Filho, F. V. Estudo epidemiológico do câncer de glândula salivar maior. Rev. Bras. Cir. Craniomaxilofac., 14(1):1-6, 2011.

Loiola, R. S.; Matos, F. R.; Nonaka, C. F. W.; Lopes, F. F. \& Cruz, M. C. F. N. Perfil epidemiológico das neoplasias de glândulas salivares diagnosticadas em São Luís-MA. J. Bras. Patol. Med. Lab., 45(5):413-20, 2009.

Moore, K. L. Fundamentos de Anatomia Clínica. $4^{a}$ ed. Rio de Janeiro, Guanabara Koogan, 2013.

Oliveira, A. S.; Rocha Ferreira, J. R. \& Blumenschein, A. R. Estudo anatômico do modelo arterial de vasos responsáveis pelo aporte sanguíneo da glândula submandibular de primatas neotropicais [Cebus apel/a, Linnaeus, 1766]. Acta Sci., 22(2):573-9, 2000.

Souza, R. P.; Oliveira Paes Junior, A. J. \& Volpato, R. O espaço sublingual. Radiol. Bras., 36(1):35-40, 2003.

Tortora, G. J. \& Nielsen, M. T. Princípios de Anatomia Humana. $12^{a}$ ed. Rio de Janeiro, Guanabara Koogan, 2013.

Vasconcelos, M. G.; Vasconcelos, R. G. ; Mafra, R. P. ; Rocha, A. G. \& Queiroz, L. M. G. Sialólito em ducto de glândula submandibular. Rev. Bras. Cienc. Saúde, 16(2):231-4, 2012.

Vidsiunas, A. K.; Rodrigues, M. F.; Bonsi, A. B. \& Boni, R. C. Avaliação de diferentes metodologias para o ensino de anatomia humana. São Paulo, Faculdade Santa Marcelina, Anais do XXIII Congresso Brasileiro de Anatomia, 2008.
Correspondence to:

Dr. André Davim

Laboratory of Human Anatomy

Centro Universitário do Rio Grande do Norte UNI-RN

Avenue Prefeita Eliane Barros, 2000. Tirol

Zip Code: 59014-540

Natal, RN

BRAZIL

Phone: + 5584 3215-2917

3215-2992

Email: anatomia@unirn.edu.br

Received: 12-01-2015

Accepted: 26-06-2015 